\title{
The influence of chlorella suspension on the quality of milk and its processing products
}

\author{
Raisat Akhmedkhanova*, Zaidin Dzhambulatov, Zemfira Gadzhaeva, Gadji Shabanov, and \\ Samira Alieva
}

Dagestan State Agrarian University named after M.M. Dzhambulatova, M. Gadzhieva street, 180, 367032 Makhachkala, Russia

\begin{abstract}
This job is devoted to the production of dairy products enriched with iodine, which accumulates naturally when chlorella (Chlorella vulgaris) suspension is introduced into the diet of lactating cows. It was found that as a result of the introduction into the diet of lactating Holstein cows during the winter stall period at the rate of 1 and 1.5 liters of chlorella suspension per head per day, the content of protein, fat and iodine in milk, as well as in macro and microelements, and almost all amino acids they are superior compare to milk samples from the experimental groups. Milk and dairy products made from cows' milk that have been fed with chlorella suspension have increased nutritional value, improved properties and a well-balanced chemical composition.
\end{abstract}

\section{Introduction}

Currently, to balance and improve the efficiency of feed, a wide range of feed additives, biostimulants of domestic and foreign production is offered, the effectiveness of which directly depends on their composition, digestibility and cost. Feed additives play a significant role in increasing productivity, optimizing metabolic processes in the animal body and preserving it. The main components of biologically active food additives, which can only be called conditionally, are synthetic substances with low digestibility and harmful to humans.

According to research by specialists, the level of health of the population is $52 \ldots 55 \%$ depends on socio-economic conditions and vital activity, including nutrition, therefore high-quality and safe products are one of the most significant factors affecting health [1-3].

For that reason, the widespread use of natural feed additives is a necessary condition to obtain environmentally friendly products free of components harmful to humans.

In this regard, numerous studies are devoted to the search for plant raw materials, which, in terms of biological value, would not be inferior to expensive protein feeds of animal and plant origin, and would significantly improve the taste and environmental friendliness of the products.[4,5].

* Corresponding author: raisatragimovna@mail.ru 
Thence, using feed additives containing various nutrients and biologically active substances that can enrich the dietis efficient.

Such natural unconventional sources of biologically active substances include microscopic plants that grow in fresh water - microalgae.

Bogdanov, N. (2007) noted that they contain in their composition all vital elements in high concentration and easily digestible form for animals, as well as in the content of vitamins that are much superior to all vegetable feed and crops of agricultural production [6]

According to I.V. Shchukin. (2015) in terms of its nutritional value, algae is not inferior to meat and is significantly superior to wheat. For example, If wheat contains $12 \%$ of protein, then chlorella contains more than $50 \%$. [7]

The results of studies by many scientists from different countries indicate the possibility of using various types of microalgae in feeding farm animals and in medicine. [8-11]

The utilization of microalgae allows reducing the usage of medications, including antibiotics, for the treatment of animals. This will allow obtaining better quality livestock products.

TretyakovE.A.Mechanikov M.V., Kulakov T.S. (2016) establushed that feeding animals during the milk period a suspension of chlorella in an amount of $0.5 \mathrm{~kg}$ per head per day increases their nutritional activity and increases average daily gains while optimizing health. [8]

Mukhanov N. B et al. (2015) note that the use of a suspension of chlorella in the feed ration of cattle makes it possible to obtain additional weight gain from $25 \%$ to $45 \%$ on young animals and to increase the safety of livestock up to $99 \%$. Milk productivity for a dairy herd increases by $15-25 \%$, while the taste and fat content of milk improve also.[9]

As noted by Veldanova M et al., (2014) a method of enriching food by usingadditives of inorganic nature has practiced to compensate the iodine deficiency, almost all over the world, which have not given the desired results .[12]

The numerous studies conducted in our country and abroad convincingly prove that the most acceptable way to obtain iodized livestock and poultry products is utilizing of plantbased feed additives in the diet, which contribute not only to healthy food and also to increase productivity. [13]

PonomarenkoYu.A. in his works notes the positive effect on the accumulation of iodine and selenium in meat and liver of broiler chickens, depending on the amount of suspension and dry chlorella, enriched with iodine and selenium. [14,15]

The production of poultry products saturated with vitamin $\mathrm{E}$, iodine, selenium, omega-3 fatty acids is rapidly developing abroad. Despite the fact that the prices for such products are several times higher than the cost of ordinary ones, they find their consumers in connection with the spread of the global trend towards healthy eating. [16]

Based on the foresaid, the best form of providing population with iodine and other microelements is to obtain food products enriched with iodine naturally, scilicet, to obtain functional products enriched with iodine, iron and other biologically active substances.

Consequently, the idea appeared to include microalgae in the diet of lactating cows to eliminate iodine deficiency in the nutrition of the animals themselves and, as a result, to obtain dairy products enriched with iodine and naturally.

In spite of numerous publications in the literature about algae, data on utilization of freshwater algae are very limited.

In this regard, it was a great interest to us to study the composition of milk and dairy products when microalgae were addedto the diet of Holstein cows in the amount of 1.0 and 1.5 liters per head per day. 
The objective of the work is to determine the optimal levels of chlorella suspension in the diet of lactating Holstein cows and to study its effect on the composition of milk and dairy products.

\section{Research methods}

To achieve this goal 3 groups of lactating Holstein cows were formed by 5 heads each, selected according to the principle of analog groupsin the peasant farm "Umarov OM". The first control group received the basic economic diet (RR), the second experimentalgroup, in addition to the basic diet, received a suspension of chlorella at the rate of 1 liter. per head per day and 1.5 liters. the third group. The studies were held during the winter period of the first five months of lactation (January-May). Feeding and housing conditions were the same for all experimental groups except of the studied factor.

In the third month of lactation from the day when chlorella suspension was introduced into the diet, average milk samples were taken from groups and were analyzed.

The data in Table 1 indicate the positive effect of chlorella suspension on the chemical composition of milk.

Table 1. Physicochemical indicators of cows' milk in the third lactation period of the Holstein breed

\begin{tabular}{|l|c|c|c|c|}
\hline \multirow{2}{*}{ Index } & \multirow{2}{*}{ units } & \multicolumn{3}{c|}{ Group, 5 heads } \\
\cline { 3 - 5 } & & 1 control & 2 experimental & 3 experimental \\
\hline Mass fraction of fat & $\%$ & 3,57 & 3,58 & 3,59 \\
\hline Dry matter & $\%$ & 12,78 & 13,0 & 13,02 \\
\hline Mass fraction of protein & $\%$ & 3,36 & 3,39 & 3,41 \\
\hline Density & & 26,68 & 26,66 & 26,67 \\
& $\mathrm{~kg} / \mathrm{m}^{3}$ & & & 9,41 \\
\hline SOMO & $\%$ & 8,55 & 9,18 & 4,89 \\
\hline Lactose & \multicolumn{4}{|c|}{ Macronutrients } \\
\hline \multicolumn{5}{|c|}{ Micronutrients } \\
\hline Calcium & $\mathrm{mg} / 1$ & 1000 & 1043 & 1080 \\
\hline Phosphor & $\mathrm{mg} / 1$ & 6,9 & 8,8 & 8,3 \\
\hline Potassium & $\mathrm{mg} / 1$ & 1300 & 1200 & 1324 \\
\hline Sodium & $\mathrm{mg} / 1$ & 470 & 500 & 518 \\
\hline Sulfur & $\mathrm{mg} / 1$ & 30 & 33 & 35 \\
\hline \multicolumn{5}{|l|}{} \\
\hline Iron & $\mathrm{mg} / 1$ & 16 & 28 & 36 \\
\hline Copper & $\mathrm{mg} / 1$ & 0,095 & 0,097 & 0,096 \\
\hline Iodine & $\mathrm{mg} / \mathrm{kg}$ & Not found & 0,20 & 0,29 \\
\hline
\end{tabular}

In terms of the content of the mass fraction of fat in milk, the control group of cows is inferior to the experimental groups - by 0.01 and $0.02 \%$ and in terms of the protein by 0.03 and $0.05 \%$.

The content of all the macronutrients presented in table 1, each of which is important for our body in its own way, is significantly higher in the milk of the experimental groups compared to the control. A similar picture is observed for microelements. The iron content in the milk of cows receiving chlorella suspension is twice as high as in the control. 


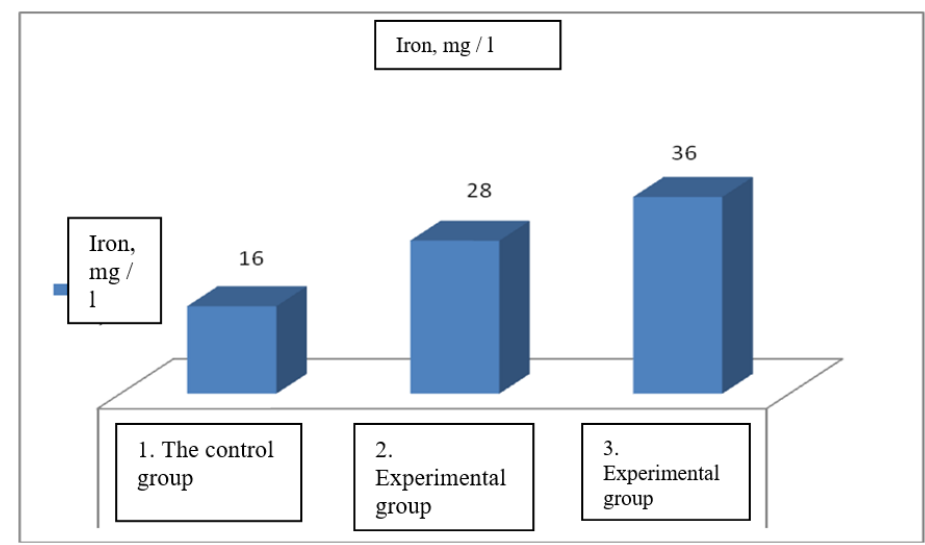

Fig. 1. Iron content in milk of cows from control and experimental groups

The presence of iodine was not detected in the milk of cows in the control group, and it contained $0.20 \mathrm{mg} / \mathrm{kg}$ in the milk of cows of the second experimental groupand the third experimental group - $0.29 \mathrm{mg} / \mathrm{kg}$. In the third experimental group, the iodine content in milk is $45 \%$ higher than in the second experimental group.

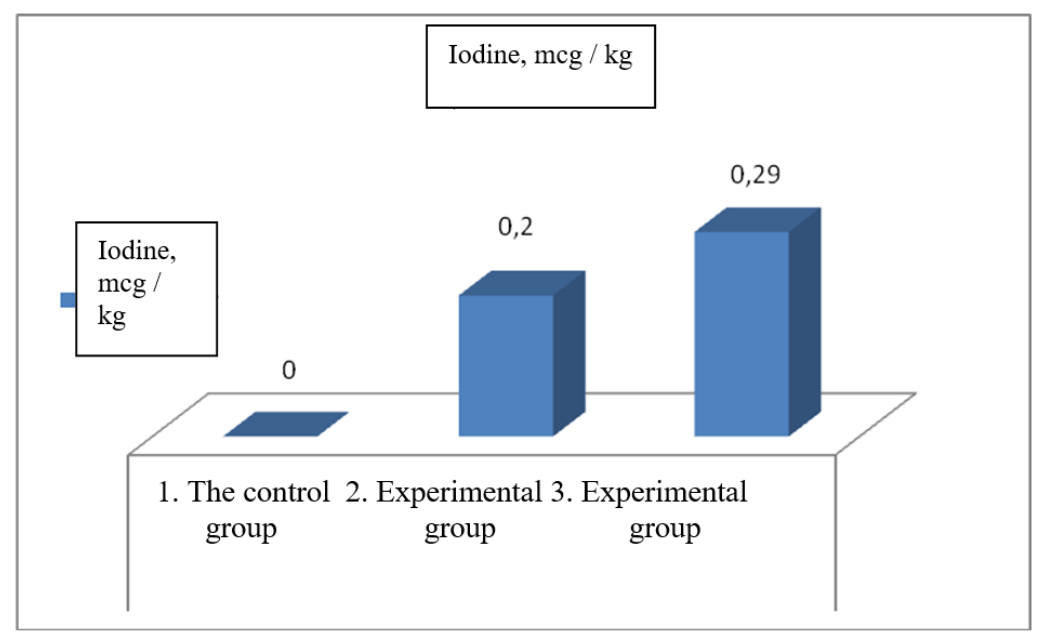

Fig. 2. The content of iodine in the milk of cows from the control and experimental groups

The study of milk for the amino acid composition (17 amino acids) showed both in terms of macro and microelements, and almost all amino acids surpass the milk samples of the experimental groups that received a suspension of chlorella (table 2).

Table 2. Amino acid composition of cows'milk in the third lactation period of the Holstein breed,\%

\begin{tabular}{|l|l|l|l|}
\hline \multirow{2}{*}{ Index } & \multicolumn{3}{|c|}{ Group, 5 heads } \\
\cline { 2 - 4 } & 1 control & 2 experimental & 3 experimental \\
\hline Lysine & 0,29 & 0,30 & 0,39 \\
\hline Histidine & 0,11 & 0,11 & 0,11 \\
\hline Arginine & 0,11 & 0,11 & 0,13 \\
\hline Aspartic acid & 0,28 & 0,28 & 0,28 \\
\hline Threonine & 1,12 & 0,13 & 1,14 \\
\hline Serine & 0,14 & 0,16 & 0,17
\end{tabular}


Table 2. Continued

\begin{tabular}{|l|l|l|l|}
\hline Glutamic acid & 0,62 & 0,65 & 0,69 \\
\hline Proline & 0,30 & 0,30 & 0,31 \\
\hline Glycine & 0,06 & 0,06 & 0,06 \\
\hline Alanin & 0,11 & 0,11 & 0,12 \\
\hline Cystine & 0,03 & 0,03 & 0,03 \\
\hline Valine & 0,21 & 0,21 & 0,22 \\
\hline Methionine & 0,07 & 0,09 & 0,10 \\
\hline Isoleucine & 0,17 & 0,17 & 0,18 \\
\hline Leucine & 0,31 & 0,32 & 0,34 \\
\hline Tyrosine & 0,16 & 0,16 & 0,17 \\
\hline Phenylalanine & 0,15 & 0,17 & 0,18 \\
\hline
\end{tabular}

Table 3. Chemical composition changes of semi-hard cheese (Montasio) when microalgae are introduced into the diet of Holstein cows

\begin{tabular}{|l|c|l|c|c|}
\hline \multirow{2}{*}{ Index } & \multirow{2}{*}{ units } & \multicolumn{3}{|c|}{ Group, 5 heads } \\
\cline { 2 - 5 } & & 1 control & 2 experimental & 3 experimental \\
\hline $\begin{array}{l}\text { Crude } \\
\text { protein }\end{array}$ & $\%$ & 30,71 & 31,25 & 32,0 \\
\hline Crude fat & $\%$ & 35,20 & 49,87 & 52,4 \\
\hline Crude ash & $\%$ & 5,54 & 6,55 & 6,73 \\
\hline Phosphor & $\%$ & 0,61 & 0,59 & 0,607 \\
\hline Calcium & $\%$ & 0,95 & 0,99 & 1,02 \\
\hline Sodium & $\%$ & 1,57 & $!, 97$ & 2,01 \\
\hline Manganese & $\mathrm{mg} / \mathrm{kg}$ & 0,17 & 0,52 & 0,55 \\
\hline Iron & $\mathrm{mg} / \mathrm{kg}$ & 5,07 & 5,70 & 5,79 \\
\hline Copper & $\mathrm{mg} / \mathrm{kg}$ & 1,02 & 1,08 & 1,07 \\
\hline Zinc & $\mathrm{mg} / \mathrm{kg}$ & 48,80 & 43,42 & 43,40 \\
\hline Iodine & $\mathrm{mcg} / \mathrm{kg}$ & Not founded & 297 & 312 \\
\hline
\end{tabular}

Analyzing results of the chemical composition of semi-hard cheese (montazio) roduced from milk from Holstein cows fed a diet enriched with chlorella suspension, showed a significant increase in the protein content in the cheeses of the second group by $1.75 \%$, and in the third - by $4.2 \%$ in relation to control. A similar picture is observed for fat content. In the cheese samples of the second and third experimental groups, the fat content is respectively higher on 41.68 and $48.86 \%$ in relation to the control. Also we can notice the increase minerals in the cheese produced from the experimental groups cows, in particular, such trace elements as iodine and iron.As in the milk, and in the samples of cheese from the control group, iodine was not detected, and in the experimental second group it was $297 \mu \mathrm{g}$ $/ \mathrm{kg}$, and $312 \mu \mathrm{g} / \mathrm{kg}$ in the third group. 


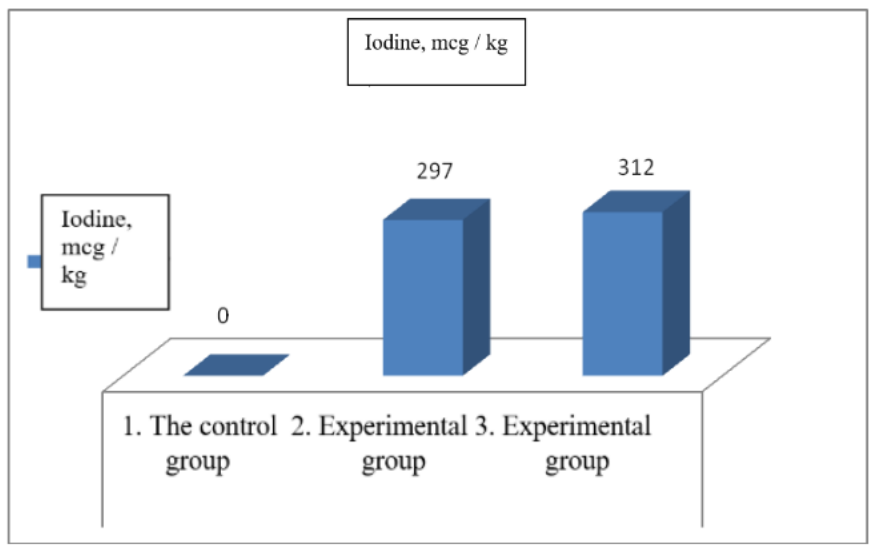

Fig. 3. Iodine content in cheese samples from control and experimental groups

Iron in the samples of cheeses from the experimental groups was found to be significantly higher than in the control group by $-12.43 \%$ in the second and $-14.20 \%$ in the third experimental groups. The copper content in the cheeses of the experimental groups was at the control level, and the zinc content was lower by 11.02 and $11.07 \%$.

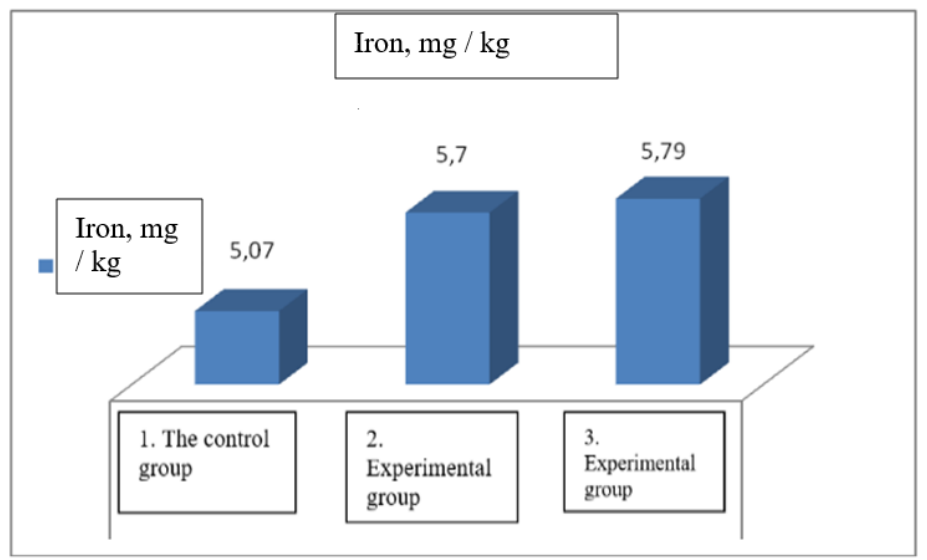

Fig. 4. Iron content in cheese samples from control and experimental groups

\section{Results and Discussion}

The utilization of chlorella suspension in the diet of Holstein cows during the winter stall period contributed to the production of milk and its processing products enriched with nutrients, in particular iodine.

\section{Conclusion}

Thus, the results of the studies carried out allow us to conclude that the use of chlorella suspension in the diet of lactating Holstein cows during the winter stall period had a positive effect on the accumulation of iodine and other biologically active substances in milk and cheese samples (montazio). 
Lastly, the biomass of algae is a rich source of essential and easily assimilated substances, which has a positive effect on obtaining functional dairy products enriched with iodine, iron and other biologically active substances.

\section{References}

1. C. J. L. Murray, A. D. Lopez, The global burden of disease. A comprehensive assessment of mortality and disability from diseases, injuries, and risk factors in 1990 and projected to 2020 (1996)

2. N.M. Aminina, E.L. Koneva A.V. E.V. Yakush, L.N. Bocharov, Materials of the XX International Scientific Conference "Health of the Nation - XXI Century", 39 (2016)

3. N.M. Aminina, Health, Medical ecology., The science, 5, 38 (2017)

4. S.M. Alieva, R.R. Akhmedkhanova, T.S. Astarkhanova, Scientific journal of KubSAU, 117(3), 1 (2016)

5. S.M. Alieva, R.R. Akhmedkhanova, Z. M. Gadzhaeva, S.G. Kozyrev, Scientific and practical journal Izvestiya Gorskogo GAU, 55(2), 64 (2018)

6. N. Bogdanov, Feeding farm animals and fodder production, 4, 12 (2007)

7. A. V. Stepova, V. V. Borisenko, V. I. Nikolaenko, Young scientist, 5-1(85), 25 (2015)

8. E. A. Tretyakov, M. V. Mechanikova, T. S. Kulakova, Young Scientist, 6.5, 102 (2016)

9. N.B. Mukhanov, E. Zh. Shorabaev, Zh. K. Dastanova, Young scientist, 7(2), 21 (2015)

10. M. Beldanova, A. Skalny, Prevention of iodine deficiency diseases - Effective medicine (2014) http://www.medeffect.ru.

11. N. Shalygo, Science and innovation, 2(180), 20 (2018)

12. WangX, WangL, CheJ, LiZ, ZhangJ, LiX, HuW, XuY, Applied Microbiology and Biotechnology, 99(14), 5843 (2015)

13. M. Kunitsyn, Agrarian review, 6, 24 (2013)

14. Yu.A. Ponomarenko, Nature management collection of scientific papers, 26, 197 (2014)

15. Yu. A. Ponomarenko, Global Science and Innovation: materials of the IV International Scientific Conference, Chicago, March 12-13 ${ }^{\text {th }}, 41,15$ (2015)

16. V. Fisinin, Livestock of Russia, 8, 6 (2009) 